\title{
Competition and globalisation in economic sciences. Selected aspects ${ }^{1}$
}

\section{Marian Gorynia ${ }^{2}$}

\begin{abstract}
The aim of the paper is to identify and assess the role of economic sciences in relation to competitiveness and globalisation, two basic concepts of the market economy. This role is to explain and interpret their essence but also to determine their potential practical usefulness, primarily in the context of economic policy development. The considerations mentioned in the article are, as a rule, of a general and universal nature and do not relate especially to any particular countries or groups of countries. The basic method employed in the study is a critical analysis of the subject literature. The paper consists of an introduction, three sections, and conclusions. Section 1 contains a basic discussion of the subject of economic sciences and describes their four features: cognitive productivity, practical usefulness, dismal nature and beauty. Section 2 presents the contribution of economic sciences to understanding and interpreting the phenomenon of competitiveness. Section 3 focuses on defining and elucidating the idea of globalisation and an examination of its most important aspects. The paper ends with eight conclusions formulated on the basis of this discussion.
\end{abstract}

Keywords: economic sciences, competitiveness, globalisation, internationalisation.

JEL codes: A11, F01, F02, F23.

\section{Introduction}

The discussion on the role played by economic sciences in the social system has always been animated and full of numerous, often contradictory, views. It was particularly intense during the global financial crisis of 2008-2013 and afterwards. In effect doubts arose over economic sciences' predictive capabilities. The main criticism was that, as has been claimed, economists were not able to effectively warn the public against the imminent crisis. Such a view should be opposed for several reasons. First, today's economic life is extremely complex.

\footnotetext{
${ }^{1}$ Article received 10 June 2019, accepted 16 August 2019.

2 Poznań University of Economics and Business, Department of International Competitiveness, Al. Niepodległości 10; 61-875 Poznań, Poland, marian.gorynia@ue.poznan.pl, ORCID: https://orcid.org/0000-0002-7633-8249.
} 
This results in a large number of national economies cooperating with each other globally which frequently makes it difficult to model economic processes. Second, economic sciences perform numerous functions, with the predictive function not being the only or most important one. Third, limited predictive capabilities are not unique to economic sciences only: they are typical of many other disciplines considered to be more advanced. Fourth, even the most accurate diagnoses and forecasts provided by economists are a necessary but not sufficient criterion for using the results of these analyses in business practice.

The aim of the paper is to present, discuss and evaluate the contribution economic sciences have made to the description, understanding and explanation of two leading and closely related categories of today's market economy, namely competitiveness and globalisation. The concepts of competitiveness and globalisation are among the most current and most frequently discussed economic issues. They are present in all discussions on the current and forward-looking situation of the world economy, national economies of individual countries, industries and sectors of individual national economies, as well as individual enterprises. At the same time they are of interest in most economic research centres around the world. That is why it is so important to answer the question as to how economic sciences deal with the explanation of these concepts taking into account these sciences' inherent limitations. The inherent nature of the limitations is not an expression of philosophical pessimism but a reflection of cognitive realism, which is one of the most important methodological postulates of contemporary economic research (Mäki, 2009).

The structure of the text is closely related to its title: it consists of three interrelated parts, making the paper a triptych built of components on economic sciences, on competitiveness and on globalisation. Section 1 gives a brief description of modern economic sciences with an indication of their most important features, including their research limitations. Section 2 is devoted to presenting the essence of the concept of competitiveness, in particular emphasizing the achievements of M. Porter. In turn Section 3 discusses the most important aspects of the second key category considered in this article, i.e. globalisation. The considerations examined refer to four levels of analysis: global (world or global economy), macroeconomic (national economies of particular countries), mesoeconomic (particular industries and sectors of individual national economies) and microeconomic (individual companies). Considerations regarding the mentioned units of analysis are intertwined.

\section{On economic sciences}

To begin with a brief answer should be given to two basic questions: "What are economic sciences?" and "What do representatives of economic sciences do?" In this text it is simplified in that economic sciences are a broader category than 
economics as such (or narrowly understood) and that they consist of all components included in the JEL classification ${ }^{3}$. Adopting a broad understanding of economic sciences means that they should not be reduced to mainstream or orthodox economics. At this point it should be noted that modern economic sciences are characterized by a large variety of approaches, among which interdisciplinary approaches deserve special attention. They include, for example, the approach of market design (Milgrom, 2009; Roth, 2012; Ockenfels, 2013). The first author gave the following definition of market design (Milgrom, 2008): "Market design is a kind of economic engineering, utilizing laboratory research, game theory, algorithms, simulations, and more. Its challenges inspire us to rethink longstanding fundamentals of economic theory".

Another question worth answering is: "Why should representatives of economic sciences take pleasure in pursuing them?" This may be because economic sciences are characterised by some positive features, or strengths, briefly presented here. Economic sciences are cognitively productive, useful in practice, positively dismal, and beautiful.

Economic sciences are cognitively productive because they perform their descriptive and explanatory function relatively effectively (or as effectively as possible) by providing answers to the questions: "What happens/happened?" and "Why does/did it happen?" (Gorynia \& Kowalski, 2013). They fulfil this function to the extent made possible by the capabilities and cognitive limitations of researchers practising all the disciplines, trying to adhere to the principle that a good theory accurately explains reality and, as such, potentially creates opportunities to use it fruitfully in practice. Economic sciences' cognitive productivity is related to their multi-model, multi-paradigm and interdisciplinary nature (Rodrik, 2015; Gorynia, 2018a, 2018b). There is no single best theory formulated as an extensive, comprehensive model. Quite the opposite: economic knowledge is partially dispersed and contained in not-fullyintegrated models that describe reality. Such is the current state of economic knowledge development and we may justifiably fear that this will not change in the future mainly due to the complexity of the subject studied.

Economic sciences' practical usefulness consists in meeting the requirement that we should accurately identify reality-governing mechanisms, which may provide a basis for developing recommendations on how to shape reality ("What should happen?") and/or formulate forecasts for the future ("What is likely to happen?"). It could be noted at this point that, as the most important stakeholder in economic sciences, society is, in fact, interested not in theory but in its practical applications, i.e. in developing recommendations for improving management practice. In their prescriptive role economic sciences consist of two components: defining the goals (values, principles) we should

\footnotetext{
${ }^{3}$ Regarding the evolution of the classification of economic sciences, Cherrier (2017) is worth recommending.
} 
work towards in our business activity and in using the available descriptive and explanatory knowledge to achieve these goals. Goals are social and political choices. Therefore, in the fulfilment of their prescriptive role, economic sciences are only partly "scientific". It is similar in the case of economic sciences' predictive function.

It should be admitted at this point that the thesis about economic sciences' cognitive productivity and practical usefulness is not universally accepted. The fact that expectations with regard to economic sciences held by society and some of their representatives are frequently excessive results at least in part from a misunderstanding of their role and, in consequence, their capabilities and limitations. Economic sciences' limited explanatory and predictive capabilities become clearer when we take into consideration the fact raised by the famous economics methodologist Blaug (1992), that other disciplines whose theories are universally considered to be highly mature (i.e. Newton's theory of gravitation, Darwin's theory of evolution, Freud's depth psychology, Durkheim's theory of suicide) also have their limitations and are prone to criticism for their imperfect descriptive-explanatory and predictive functions. In this context economic sciences' complexes are partly unjustified. What is more we could point to numerous cases of cognitive deficits in other disciplines, such as meteorology, medicine, geology/geophysics.

Another feature of economic sciences is that they are positively dismal. Their dismal nature, about which Carlyle, Arrow and Wilkin (Wilkin, 2016) have written such interesting texts, is related to the fact that the resources available to people are scarce and not everything can be done/achieved immediately. Thus interpreted pessimism can be perceived as economic sciences' disadvantage or weakness. After some reflection, however, it is not hard to notice that this feature is actually their strength: through their main focus of interest, which is efficiency, economic sciences impart a rational dimension to human behaviour, which is not characterised by an awareness of resource constraints but results in establishing a hierarchy of (unlimited) human needs to be satisfied by means of scarce resources. Paradoxically, therefore, owing to their dismal nature, economic sciences are useful because their role in society is to rationalise people's economic behaviour thanks to which they can reach a higher level of prosperity.

The final advantage of economic sciences is that they are beautiful. This is an aesthetic and philosophical statement rather than one that is scientifically verifiable. In this context we should take into consideration the classification of cultures made by Friedrich Nietzsche, who distinguished two types of beauty (Fiedor, 2016):

- Apollonian beauty-Plato-harmony and proportion, autonomous value, ideal being, exists regardless of its physical or sensory basis,

- Dionysian beauty-different from Apollonian, also joyful but often painful, could also be antithetical towards reason, often full of pain, madness and possession; Apollonian beauty is a veil for Dionysian beauty. 
To conclude this section it would be advisable to mention the philosophical assumptions underlying the discussion presented in this paper. The basic assumption is philosophical realism which can be described through three characteristics (Hardt, 2013; Gorazda, Hardt, \& Kwarciński, 2016): the reality of the external world, the observable world's independence from the cognising subject; a multi-layered structure of reality-a hierarchical structure of the Universe, various units/levels of analysis; recognition/knowledge of the world-the world can be cognisised, cognition is gradual, research progress is possible. Philosophers of economics vary in terms of their ontological, epistemological and methodological approaches. The adoption of philosophical realism as a basis for the present discussion is consistent with the dominant approach used in today's economic research. At the same time this involves rejecting other possible conventions, including constructivism, instrumentalism or "empty" formalism (Scheurer, 2016).

The above mentioned features of economic sciences mean that, on the one hand, their commitment to scientific cognition and of explaining the two leading market economy categories that are the subject of this article's consideration can potentially lead to theoretically and practically useful results. On the other hand, one should be aware that the results of scientific cognition of the issues of competitiveness and globalisation may not be completely satisfactory due to the indicated limitations of these sciences and also due to the high complexity of systems in which competition and globalisation processes take place.

\section{On competitiveness}

In the twentieth century competitiveness became one of the most important and most intensively studied economic categories. Research into competitiveness derives from an interest in one of the basic categories of the market economy, namely competition. First of all we should note the large number of conceptions of competition found in economic sciences: the classical school (Smith, Malthus, Ricardo, Mill), Marxian theory, the neoclassical school (perfect competition theory, imperfect competition, Clark and workable competition, monopoly, oligopoly), Keynes on competition, the Austrian school (Schumpeter in particular), evolutionary economics, game theory and trends in managerial economics (Gorynia, 2002).

To keep things as simple as possible we can assume that competitiveness is the skill of competing, i.e. operating and surviving in a competitive environment. Related as it is to the aforementioned philosophical realism, the assumption of a hierarchical structure of the universe implies the carrying out of multilevel competitiveness research. This involves distinguishing several possible units or levels of the analysis of competitiveness: micro-micro, micro, meso (industry, sector, region), macro, and regional (group of countries). 
Worthy of note are several features of contemporary research into competitiveness. One is the difficulty in defining competitiveness. The variety of definitions can be seen by studying the work of such authors as Dornbusch and Fischer, Porter, Casson, and Krugman (Gorynia, 2002). It seems that a good solution in this situation is offered by "Porter's compromise", according to which competitiveness simply means productivity. Such an approach rejects various questionable ways of interpreting competitiveness, namely: competitiveness understood as a macroeconomic phenomenon determined by exchange rates, interest rates and budget deficits; competitiveness identified with a large and cheap workforce; competitiveness resulting from the possession of natural resources; competitiveness created by economic policy; competitiveness interpreted as an effect of adopting a specific management style.

Another notable feature of competitiveness studies is a tendency to carry out "mono-level" research related to separate levels of analysis and accompanied by the absence of a synthesis of single-level approaches (micro-competitiveness, meso-competitiveness, macro-competitiveness). Against the backdrop of this drawback of competitiveness analyses the approach used in Porter's Five Forces model recommends the recognition and development of a competitive strategy without ignoring the context of the industry/sector to which a given company belongs (Porter, 1980).

The next distinctive characteristic of today's advanced research into competitiveness is the introduction of new analytical categories which facilitate the description and understanding of complex economic reality. This is especially true of such categories as: the concept of systemic competitiveness, the concept of institutional competitiveness, ex ante competitiveness vs ex post competitiveness, supply competitiveness vs demand competitiveness, intraindustry competitiveness vs inter-industry competitiveness, competitiveness in the domestic market vs competitiveness in a foreign market and corporate competitiveness, consisting of three basic components: competitive potential, competitive position and competitive strategy (Gorynia, 2002; Noga, 1995).

Contemporary achievements in the area of competitiveness research are dominated by the outstanding and unique work of Michael Porter. It has been built upon several conceptual pillars which, over time, have become part of the canonical economic, managerial, business and administrative knowledge. These pillars are:

- the concept of competitive strategy-Porter's Five Forces model, types of competitive strategy (Porter, 1979, 1980),

- competitive advantage theory-value-added chain, value system (Porter, 1985),

- the nature of competition in global industries (Porter, 1986),

- the foundations of the competitive advantage of nations-Porter's Diamond model (Porter, 1990, 1991),

- the foundations of contemporary cluster theory (Porter, 1998a), 
- the idea of shared value-doing business and simultaneously solving social problems (Porter, 2008).

From the perspective of the research interests of those who study international competitiveness and globalisation the most valuable achievement seems to be what is referred to as Porter's Diamond model whose creator emphasised, as well as conceptually and analytically explored, the foundations of the economic prosperity of companies or nations (see Figure 1). In his view, identifying these foundations requires answers to the following questions:

Why has a country become a base for successful international competitors in a given industry?

Why can companies that are based in a given country create and maintain a competitive advantage in relation to their most dangerous global rivals in a given field?

Why do so many global leaders in a given industry tend to be based in one country rather than another?

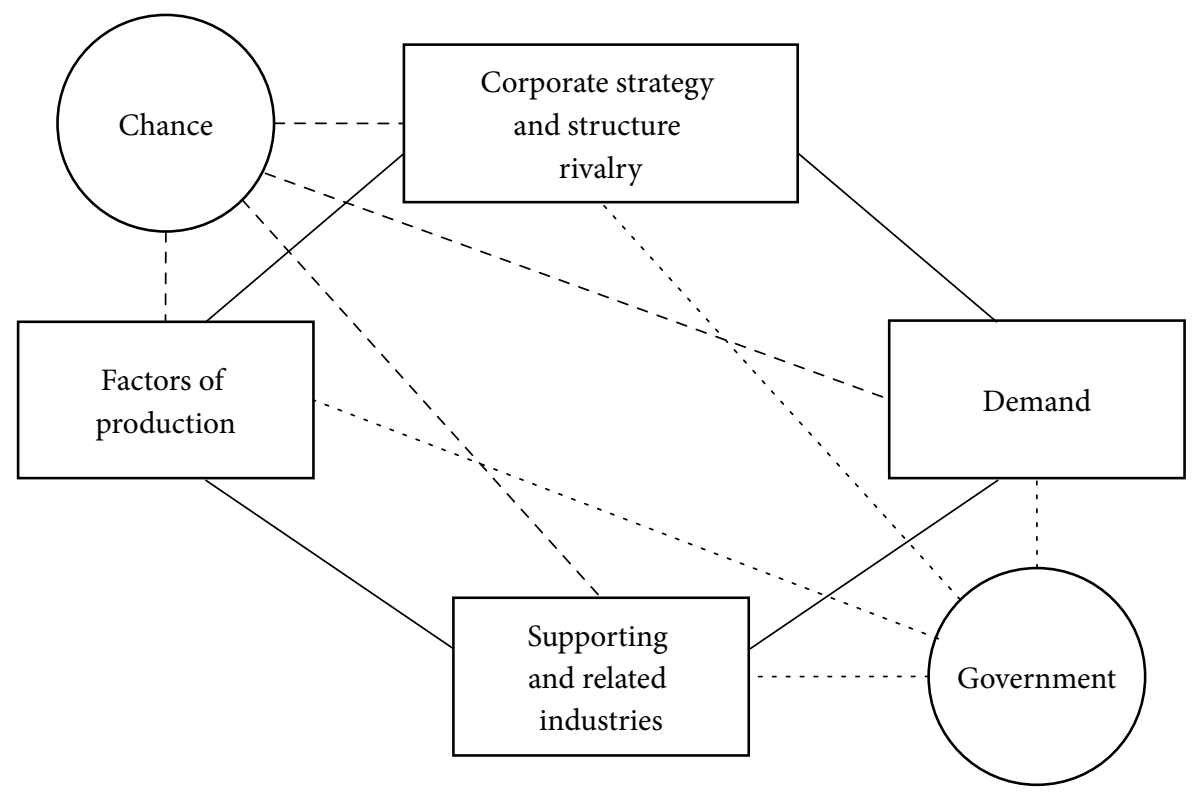

Figure 1. Porter's Diamond model-modified

Source: Adopted from Porter (1991, p. 127).

The issue of competitiveness is considered to be one of the main determinants of the prosperity and wealth of nations. It is becoming of central importance in the operation and competition of open national economies in the global market. In this way competitiveness is becoming a basic variable in globalisation analyses. 
The relationships between the categories of competitiveness and globalisation considered in this text are best seen against the background of the concept of competition. On the one hand, competition is a base, starting category with which the issue of competitiveness is related. On the other hand, competition is an immanent attribute of a market economy, it is the core of globalisation processes.

These relationships are well reflected in the quote from Porter's book On Competition (2008, p. XI): “Competition is one of society's most powerful forces for making things better in many fields of human endavour. The study of competition and the creation of value, in their full richness, have preoccupied me for several decades. Competition is pervasive, whether it involves companies contesting markets, countries coping with globalization, or social organizations responding to societal needs... This is true today than ever before, as competition has intensified dramatically over the last several decades in almost all domains. It has spread across geography, so that nations must compete to maintain their existing prosperity, much less enhance it. Competition has also spread to all sectors of society, including fields like arts, education, health care, and philanthropy, where are growing needs but scarce resources."

It is worth noting that the previously signalled pillars of Porter's achievements have played and still play an important role in generating progress in competitiveness research. This role can be understood in two ways. First, Porter's original concepts are redefined and developed by their author. Examples that show the role of the Internet in developing strategies and building competitiveness (Porter, 2001), research bringing together the two aspects of competing across borders-location (configuration) and global networks (coordination) (Porter, 1998b), works linking strategy with philanthropy and social corporate responsibility (Porter \& Kramer, 2002, 2006), concept of shared value (Porter \& Kramer, 2011), or the role of communication technologies in building the company's strategy (Porter \& Heppelmann, 2014, 2015). On the other hand, it should be noted that Porter's concepts were the starting point or inspiration for the development of modern trends in research on competitiveness, such as smart specialization, cities' competitiveness, regions' competitiveness, institutional competitiveness and fragmentation of supply chains.

In summing up the presentation of Porter's contribution to understanding the phenomenon of competitiveness it can be further emphasized that his research is characterized by taking into account many levels or units of analysis. The starting category in Porter's studies was the industry or the national economy sector. Then Porter's attention evolved successively towards activities, business units, corporations, regions, clusters and finally entire national economies. 


\section{On globalisation}

When discussing globalisation which is one of the concepts most frequently used in today's economic discourse, it should be observed that the basic-level issue is that of internationalisation, which in the context of the economy means, most simply, international cooperation, which in turn can take various forms. On the other hand, globalisation, in the economic sense, is a special case of internationalisation, characterised by the following features:

- globalisation is a logical consequence of the market economy's development to date and a natural stage in its evolution; in other words, it is inherent and inevitable,

- intensity, universality (global reach), uniformity, unification, and standardisation of operations on a global scale are the basic characteristics of participants in globalisation activities,

- globalisation is a more (the most?) advanced stage of internationalisation,

- the most significant manifestations of globalisation are international trade (export, import), foreign direct investments, and international financial (capital) markets; a special part here is played by information technology and the Internet.

We should note considerable differences in the understanding of globalisation, particularly the possible perceptions of globalisation in terms of its opportunities, threats, and consequences. From this point of view the extensive subject literature (Al-Rodhan \& Stoudmann, 2006) distinguishes four basic approaches to understanding globalisation: a predominantly enthusiastic approach slightly tempered by reason which can be referred to as a pro-globalisation approach, approving of globalisation (though not blindly) (Bhagwati, 2004); an approach that could be described as concerned reflection, characterised by a balanced understanding of the idea of globalisation (Streeten, 2001); an approach with a large dose of suspicion, strongly critical, but not totally negative (Stiglitz, 2002); an approach questioning the idea of globalisation, which manifests itself through ideas and policies referred to as new protectionism and new nationalism (i.e. the actions of President Trump's administration and similar governments) (Rodrik, 2017).

The task of classifying and understanding the numerous and diverse approaches to interpreting globalisation and its effects may be facilitated by accurately presenting those areas where globalisation manifests itself. This is possible thanks to Bhagwati's conception (Bhagwati, 2004) identifying major opportunities and threats of globalisation which can be called 10 GLOBALISATION ANTINOMIES. The conception distinguishes the following ten operationalised areas of opportunities and threats generated by globalisation:

- Poverty: diminished-enhanced.

- Child labour: reduced-increased.

- Status of women: helped-harmed. 
- Democracy: promoted-constrained.

- Culture: enriched-imperilled.

- Wages and labour standards: rising_falling.

- Environment: improved-deteriorated.

- Corporations: beneficial-predatory.

- Crime: falling-rising.

- Health: improving-regressing. This list of areas is by no means complete; it is open and, depending on the purposes of analysis, can be extended to include other elements. The above concept helps us realise that each area is dialectical, each has both opportunities and threats and the final outcome depends on the behaviour of participants in globalisation processes (individuals, companies, international organisations, governments, etc.).

Contrary to appearances Bhagwati's approach does not differ radically from Stiglitz's (2002). The Nobel Prize winner's critical approach to globalisation boils down to highlighting five factors. The first one is unfair rules of the game, imposed by stronger, more developed countries. The second objection is connected with the fact that globalisation processes can be oriented solely towards profit and material values, without regard for other aspects. Thirdly Stiglitz mentions the undemocratic limitation of many developing countries' sovereignty. The fourth point of criticism is the uneven distribution of benefits from globalisation and-at the same time-the losses suffered by some participants in the process. The last factor questioned by Stiglitz is that the economic system imposed on many developing countries is unsuitable for their traditions, culture and development challenges. As has been noted Stiglitz's approach is critical, though not totally negative. However he also recommends making corrections to the globalisation process with a view to increasing world prosperity.

On the other hand the most serious challenge to globalisation may be antiglobalism or negating globalisation, exaggerating its weaknesses and perceiving it only as a threat. In other words what seems to be particularly dangerous is transferring political populism and nationalism to economic policy, something that is sometimes referred to as new protectionism or new nationalism (Rodrik, 2017; Kołodko \& Koźmiński, 2017). The potentially negative impact of these conceptions on the level of global prosperity should be particularly strongly emphasised. Rodrik (2017) outlines three possible scenarios in this context. The first one is called: bad-situation similar to that of the 1930s: collapse of global economic cooperation and emergence of far-right and far-left regimes, the second: $u g l y$-creeping populism and protectionism eroding both liberal democracy and an open global economy, and the last one: good-democratic restoration of a balance which departs from hyper-globalisation and restores greater national sovereignty.

In addition to identifying the general manifestations, effects and determinants of globalisation it is advisable to focus on its operational aspect. One 
such approach at a lower level of abstraction is to list the most important globalisation-related challenges identified by the Millennium Project Think Tank (2018), which lists fifteen operational challenges to the world. They can be classified into several categories such as natural (climate change, clean water, natural resources), demographic (population), economic (sustainable development, energy demands), social (shared values, status of women, education and learning), political (democracy versus authoritarian regimes), technological (scientific and technological breakthroughs; global information \& communications technologies along with machine intelligence, big data, and cloud computing, and ethical (ethical market economies-the gap between rich and poor, ethical considerations and global decisions).

The list makes us aware of the considerable scale of globalisation-related challenges that are facing humanity. In this context Kołodko (2013, p. 109) seems to be right when he argues that "The maturity of globalisation should be perceived, above all, from the viewpoint of the systemic capacity to coordinate economic policy on a global scale." It should be additionally pointed out that the literature offers also other, somewhat different, approaches to the most important globalisation-related problems. To give one example Kołodko (2013, p. 166) presents what he refers to as a dozen Great Matters of the Future.

Finally we could ask about a prescriptive globalisation vision that would meet rationality criteria. It seems that a starting point for formulating such a vision should be the observation that, on the one hand, the market is the best mechanism for allocating and coordinating economic activity; on the other, the market alone will not fix everything or be able to meet the aforementioned challenges. It seems that Bhagwati's statement (2004, p. 32) quoted above-that "Globalization is good but not good enough"- should be considered a balanced one. It implies that it is not a good solution to oppose globalisation, to fight its manifestations, or to build barriers and obstacles to it. Since globalisation is not only inevitable and inherent but can also be good and beneficial, everything needs to be done to make it be like that. For this to happen we should recall Stiglitz's view that numerous measures are needed to regulate the functioning of the international political and economic community (Stiglitz, 2002). In particular we should point to the indispensability of global coordination-in conditions of openness national economic policies are less efficient so common problems require joint remedial action as well to the need for public international institutions, changes in governing, transparency, including reforms of the International Monetary Fund and the global financial system, reform of the World Bank and development aid, reform of the World Trade Organization, ensuring a balance of trade.

In conclusion it should be strongly emphasised that the path towards globalisation with a human face is obviously long and winding but definitely possible. Its watchword should be inclusiveness. In the long run the main theoretical condition for any cooperation is based on a simple truth: firstly, for 
cooperation to be successful it must generate advantages when compared to lack of cooperation; secondly, each participant in cooperation needs to have a satisfying share in its fruits (otherwise they will not enter into cooperation) (Lorange \& Contractor, 2002).

Another element to be taken into consideration is the answer to the question about the state's economic policy or, more generally, the state's role in such a situation. The issue is worth considering because having a favourable place in the globalisation process from the perspective of an individual country is synonymous with a higher level of prosperity. At the same time it should be underlined that globalisation does not so much reduce the role of the state as influence its changes. In particular the state's systemic role is on the increase which consists of creating conditions for doing business-the state's responsibility covers such spheres as law, order, property rights and contract enforcement. The state's responsibilities also include creating laws and regulations on an international scale in such areas as intellectual property rights, environmental protection, competition policy, tax policy, trade barriers, technical standards, etc.. There appears, however, a parallel call here for the continual creative destruction of the state's systemic role which by definition needs to undergo changes. The state's involvement should also include supporting international competitiveness by ensuring an adequate quantity and quality of resources (human capital, inclination to innovation, efficient financial market), promoting lower transaction costs, creating a positive investment climate and influencing business ethics. What is no less important is the state's role in supporting innovation which is the subject of numerous disputes. Careful thought should also be given to building and supporting economic patriotism.

However when creating a range of recommendations for economic policy under globalisation it is worth bearing in mind the following statement by Friedman (1977, pp. 41-42): "Nothing creates as many jobs for economists as the state's control and interventionism. This is why all economists are schizophrenic: their research discipline, deriving from Smith, makes them favour the market; their own interest makes them favour interventionism. In effect, a significant part of the community of economists was forced to reconcile these two opposing forces by favouring the market in general and opposing it in individual cases."

It seems that the following ideas could constitute the main sources of inspiration for creating a range of general recommendations for economic policy of any individual country under the conditions of globalisation (Gorynia, 2018c): post-Kaleckian and post-Keynesian economics as a base for economic policy (Osiatyński, 2017); Porter's Diamond Model (Porter, 1998, 2008); new pragmatism versus new nationalism (Kołodko, 2014; Kołodko \& Koźmiński, 2017); New Global Governance (Serra \& Stiglitz, 2016); new industrial policy (Rodrik, 2007, 2008), Lin (market failures, the facilitating state) versus Chang (policy failures, limits of human cognition, incentives) controversy (Lin \& Chang, 2009); and Gomułka's concept of the mechanisms of technological change (Gomułka, 
2017). As can be seen the list of possible theoretical inspirations is quite long. Some of the proposals are mutually complementary while others are contradictory and mutually exclusive. In the absence of clear recommendations for economic policy it is often recommended that in such conditions the actually economic policy pursued should be characterised by a pragmatic rather than orthodox approach (Kołodko, 2014).

\section{Conclusions}

On the basis of the above discussion several conclusions can be formulated. The present paper attempts to demonstrate that economic sciences are a fascinating research area. This view is based on several of their features which can be presented as follows: economic sciences are productive cognitively, practically useful, positively dismal and beautiful. One of the most important issues addressed by today's economic sciences is the category of competitiveness. Economic sciences today have developed concepts and methods showing a relationship between prosperity and competitiveness.

Economic sciences perceive globalisation as an objective and inexorable process and a key to the future well-being of global civilisation. Using this key consists of building and maintaining competitiveness. From this perspective globalisation is beneficial for the world, an idea that has been best formulated by Bhagwati: "Globalization is good but not good enough." A positive global effect of globalisation, however, does not mean that it is good and beneficial for everybody (states, companies or people). A basis for one's attitude towards globalisation is the distribution of the benefits from globalisation. A precondition for a better use of benefits from globalisation is inclusive globalisation, which allows all participants in globalisation to enjoy its benefits, both internationally and domestically. One of the greatest threats to the progress of civilisation is blind anti-globalism.

\section{References}

Al-Rodhan, N. R. F., \& Stoudmann, G. (2006). Definitions of globalization: A comprehensive overview and a proposed definition. Geneva: Geneva Center for Security Policy. Bhagwati, J. (2004). In defense of globalization: With a new afterword. Oxford: Oxford University Press.

Blaug, M. (1992). The methodology of economics or how economics explain. Cambridge: Press Syndicate of the University of Cambridge.

Cherrier, B. (2017). Classifying economics: A history of the JEL codes. Journal of Economic Literature, 55(2), 545-579. 
Fiedor, B. (2016). Ekonomia a piękno - kilka refleksji. In S. Czaja, \& A. Graczyk (Eds.), Ekonomia i środowisko. Księga jubileuszowa Profesora Bogusława Fiedora (s. 108-121). Wrocław: Wydawnictwo Uniwersytetu Ekonomicznego we Wrocławiu. Friedman, M. (1977). From Galbraith to economic freedom (Occasional Paper 49). London: Transatlantic Arts.

Gomułka, S. (2017). Instytucje i mechanizmy długo- i średniookresowego wzrostu gospodarczego w skali globalnej. Studia Ekonomiczne, XC(3), 343-352.

Gorazda, M., Hardt, Ł., \& Kwarciński, T. (Eds.). (2016). Metaekonomia: zagadnienia z filozofii ekonomii. Kraków: Copernicus Center Press.

Gorynia, M. (Ed.). (2002). Luka konkurencyjna na poziomie przedsiębiorstwa a przystapienie Polski do Unii Europejskiej. Poznań: Wydawnictwo Akademii Ekonomicznej w Poznaniu.

Gorynia, M. (2018a). Współczesne nauki ekonomiczne: tożsamość, ewolucja, klasyfikacje. Ekonomista, 5, 497-522.

Gorynia, M. (2018b). O pięknie nauk ekonomicznych. Studia Ekonomiczne, XCVI-XCVII(1-2), 142-166.

Gorynia, M. (2018c). Innowacyjność, produktywność i konkurencyjność gospodarki a międzynarodowa współpraca gospodarcza. Ruch Prawniczy, Ekonomiczny i Socjologiczny, 80(4), 209-228.

Gorynia, M., \& Kowalski, T. (2013). Nauki ekonomiczne i ich klasyfikacja a wyzwania współczesnej gospodarki. Ekonomista, 4, 457-474.

Hardt, Ł. (2013). Studia z realistycznej filozofii ekonomii. Warszawa: Wydawnictwo C.H. Beck.

Kołodko, G. (2013). Dokąd zmierza świat. Ekonomia polityczna przyszłości. Warszawa: Prószyński i S-ka.

Kołodko, G. (2014). Nowy pragmatyzm, czyli ekonomia i polityka dla przyszłości. Ekonomista, 2, 161-180.

Kołodko, G., \& Koźmiński, A. (2017). Nowy pragmatyzm kontra nowy nacjonalizm. Warszawa: Prószyński i S-ka.

Lin, J., \& Chang, H.-J. (2009). Should industrial policy in developing countries conform to comparative advantage or defy it? A debate between Justin Lin and Ha-Joon Chang. Development Policy Review, 27(5), 483-502.

Lorange, P., \& Contractor, F. J. (Eds.). (2002). Cooperative strategies and alliances in international business: Joint ventures and technology partnership (vol. 2). Oxford: Elsevier Science Ltd.

Mäki, U. (Ed.). (2009). The methodology of positive economics: Reflections on the Milton Friedman legacy. Cambridge: Cambridge University Press.

Milgrom, P. (2009, November 5). The promise and problems of (auction) market design. Nemmers Prize Lecture.

Noga, A. (1995). Zmiana pozycji konkurencyjnej polskich przedsiębiorstw. Gospodarka Narodowa, 6, 15-19.

Ockenfels, A. (2013). Marktdesign. In Gabler Wirtschaftslexikon. Wiesbaden: Springer Gabler Verlag.

Osiatyński J. (2017). Quo vadis euro-Unio? Perspektywa ekonomii postkeynesowskiej. Ekonomista, 3, 293-311. 
Porter, M. E. (1979). How competitive forces shape strategy. Harvard Business Review, 57(2), 137-145.

Porter, M. E. (1980). Competitive strategy. Techniques for analyzing industries and competitors. New York: Free Press.

Porter, M. E. (1985). The competitive advantage: Creating and sustaining superior performance. New York: Free Press.

Porter, M. E. (Ed.). (1986). Competition in global industries. Boston: Harvard Business School Press.

Porter, M. E. (1990). The competitive advantage of nations. Harvard Business Review, 68(2), 73-93.

Porter, M. E. (1991). The competitive advantage of nations. London: Macmillan.

Porter, M. E. (1998a). Clusters and the new economics of competition. Harvard Business Review, 76(6), 77-90.

Porter, M. E. (1998b). Competing across locations: Enhancing competitive advantage through a global strategy. In M. E. Porter, On competition. Boston: Harvard Business Review Book Series.

Porter, M. E. (2001). Strategy and the Internet. Harvard Business Review, 79(3), 62-78.

Porter, M. E., \& Kramer, M. R. (2002). The competitive advantage of corporate philanthropy. Harvard Business Review, 80(12), 56-68.

Porter, M. E., \& Kramer M. R. (2006). Strategy and society: The link between competitive advantage and corporate social responsibility. Harvard Business Review, 84(12), 78-92.

Porter, M. E. (2008). On competition. Updated and Expanded Edition. Boston: A Harvard Business Review Book.

Porter, M. E., \& Kramer, M. R. (2011). Creating shared value. How to reinvent capitalism-and unleash a wave of innovation and growth. Harvard Business Review, 89(1), 62-77.

Porter, M. E., \& Heppelmann, J. E. (2014). How smart, connected products are transforming competition. Harvard Business Review, 92(11), 64-88.

Porter, M. E., \& Heppelmann J. E. (2015). How smart, connected products are transforming companies. Harvard Business Review, 93(10), 96-114.

Rodrik, D. (2007). Normalizing industrial policy. Cambridge: John F. Kennedy School of Government, Harvard University.

Rodrik D. (2008). Industrial policy: Don't ask why, ask how. Middle East Development Journal, 1(1), 1-29.

Rodrik, D. (2015). Economics rules: Why economics works, when it fails, and how to tell the difference. Oxford: Oxford University Press.

Rodrik, D. (2017). Populism and the economics of globalization. AIB Conference, Dubai. Roth, A. E. (2012, December 8). The theory and practice of market design. Nobel Lecture. Scheurer, B. (2016). Konstruktywizm w ekonomii. In M. Gorazda, Ł. Hardt, \& T. Kwarciński (Eds.). (2016), Metaekonomia: zagadnienia z filozofii ekonomii. Kraków: Copernicus Center Press.

Serra, N., \& Stiglitz, J. E. (Eds.). (2016). The Washington consensus reconsidered. Towards a new global governance. Oxford: Oxford University Press.

Stiglitz, J. E. (2002). Globalization and its discontents (vol. 500). Washington: W.W. Norton Company. 
Streeten, P. (2001). Globalisation: Threat or opportunity?. Copenhagen: Copenhagen Business School Press.

Think Tank Millennium Project (2018). Retrieved from http://www.millennium-project.org/

Wilkin, J. (2016). Instytucjonalne i kulturowe podstawy gospodarowania: humanistyczna perspektywa ekonomii. Warszawa: Wydawnictwo Naukowe Scholar. 